INTER NATIONAL MONETARY FUND
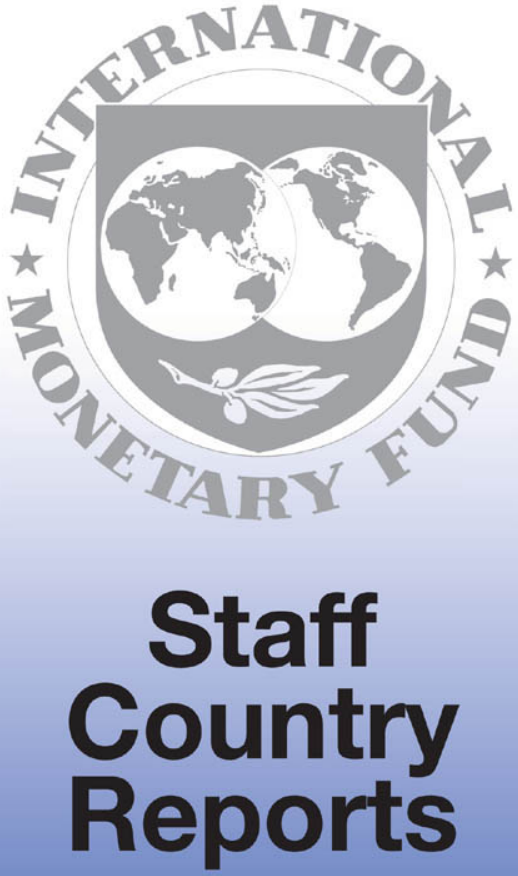


\section{Burkina Faso: Report on the Observance of Standards and Codes-Fiscal Transparency Module}

This Report on the Observance of Standards and Codes on Fiscal Transparency Module for Burkina Faso was prepared by a staff team of the International Monetary Fund as background documentation for the periodic consultation with the member country. It is based on the information available at the time it was completed on July 2, 2002. The views expressed in this document are those of the staff team and do not necessarily reflect the views of the government of Burkina Faso or the Executive Board of the IMF.

The policy of publication of staff reports and other documents by the IMF allows for the deletion of market-sensitive information.

To assist the IMF in evaluating the publication policy, reader comments are invited and may be sent by e-mail to Publicationpolicy@imf.org.

Copies of this report are available to the public from

International Monetary Fund - Publication Services

$70019^{\text {th }}$ Street, N.W. - Washington, D.C. 20431

Telephone: (202) 623-7430 - Telefax: (202) 623-7201

E-mail: publications@imf.org Internet: http://www.imf.org

Price: $\$ 15.00$ a copy

International Monetary Fund

Washington, D.C. 
This page intentionally left blank 


\section{INTERNATIONAL MONETARY FUND}

\section{BURKINA FASO \\ Report on the Observance of Standards and Codes (ROSC) Fiscal Transparency Module}

Prepared by the Fiscal Affairs Department

Approved by A. Bio-Tchané and Teresa Ter-Minassian

July 2,2002

\section{Executive Summary}

This report provides an assessment of the fiscal transparency standards in Burkina Faso in relation to the requirements of the MM Code of Good Practices on Fiscal Transparency based on the authorities' response to the questionnaire and other information provided by them.

Burkina Faso has made progress in recent years in increasing the level of fiscal transparency: the legislative basis has been strengthened; a medium-term expenditure framework has been implemented; an integrated financial management and information system is largely in place; and the preparation of program budgets will allow the budget to focus increasingly on government objectives.

There are a number of areas where improvements are needed. Most measures can however be implemented relatively easily to substantially improve the availability of information on government policy objectives, budget preparation and execution available to the National Assembly and the public. The two areas where a more concentrated effort is required are the Audit Court and the measures to ensure that the legally mandated decentralization and deconcentration does not undermine fiscal transparency. Information on central govermment expenditures (payments order basis) is available within 3 weeks of end-month, while more comprehensive data are available only with a considerable lag. Information on donor-financed projects is not fully consolidated into the budget outturn, making it difficult to assess budget implementation. Most periodic fiscal reports are only internally available for use within the Ministry of Economy and Finance. Internal audit procedures are mostly undertaken to answer specific requests, and the external audit functions are weak. Audited annual accounts of the government are available only through 1994.

The authorities are committed to improving fiscal transparency, a goal that will be facilitated by the implementation of a range of WAEMU directives. Staff comments on this report indicate that priority areas for improvement include the need for: (i) full establishment of external audit functions and strengthening of internal and external audit functions (as well as a clear separation of responsibilities); (ii) additional steps to strengthen the legal framework, including adoption of a new organic budget law; and (iii) substantial improvements in information made available to the public and the National Assembly regarding government finances. 
Contents

$\underline{I}$

Introduction... .4

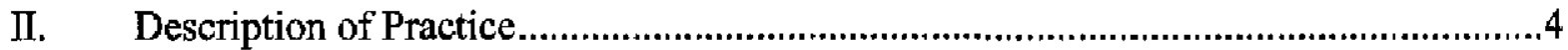

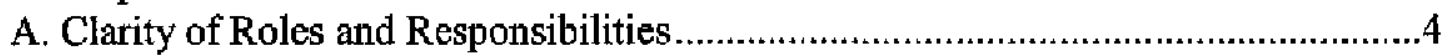

B. Public availability of information.................................................................

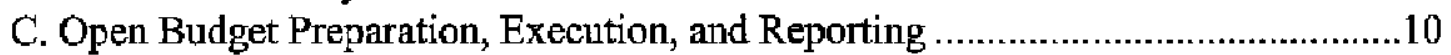

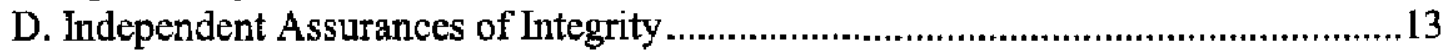

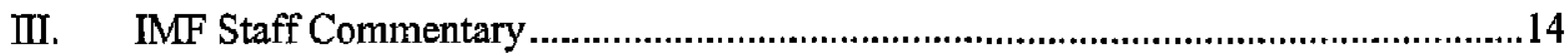

Annex

I. Burkina Faso: Government Equity Participations in the Economy .17 


\section{ABBREVIATIONS AND ACRONYMS}

BCEAO

CCP

CET

CNE

EU

GDDS

GFS

INSD

IFMIS

OHADA

PRSP

SDDS

SNA

WAEMU
Central Bank of West African States

Comptes Chèques Postaux/ Postal Checking Accounts

Common External Tariff (WAEMU)

Caisse Nationale d' Épargne/Postal Savings Bank

European Union

General Data Dissemination Standards (of IMF)

Government Financial Statistics (of IMF)

National Institute of Statisties

Integrated Financial Management and Information System

Organisation pour l'Harmonisation en Afrique du Droit des Affaires

/Organization for the Harmonization of Business law in Africa

Poverty Reduction Strategy Paper

Special Data Dissemination Standards (of IMF)

System of National Accounts

West African Economic and Monetary Union 


\section{INTRODUCTION ${ }^{1}$}

1. This draft report provides an assessment of fiscal transparency practices in Burkina Faso against the requirements of the IMF Code of Good Practices on Fiscal Transparency. The authorities have completed the fiscal transparency questionnaire prepared by the IMF staff. The assessment has two parts: the first part is a description of practices, prepared by the IMF staff on the basis of the questionnaire response and additional information provided by the authorities; and the second part is an IMF staff commentary on fiscal transparency in Burkina Faso.

\section{DESCRIPTION OF PRACTICE}

\section{A. Clarity of Roles and Responsibilities}

2. General government can be clearly defined. The 1997 Constitution, the organic budget law and government decrees provide a comprehensive basis for defining general government that corresponds to international statistical definitions Government Financial Statistics (GFS) or System of National Accounts (SNA). General government includes central government, autonomous or semi-autonomous agencies dependent on transfers from the government, and local governments (see paragraph 4 below). ${ }^{2}$ The central government budget captures transfers to autonomous or semi-autonomous agencies. However, consolidated data on general government is incomplete. For example, information on own revenues and on some expenditure items for local governments is difficult to obtain under the current structure. However, this information can be obtained from the respective agencies. I. There are only a limited number of special accounts, and these are captured in the central government budget. The activities of public enterprises are clearly distinguished from government entities.

\section{The functions and responsibilities of the executive, legislative, and judicial} branches of government are clearly defined by law, including the constitution. These texts are currently being brought into conformity with the directives of the European Unit (EU) and those of the West African Economic and Monetary Union (WAEMU) regarding the

\footnotetext{
${ }^{1}$ Discussions were held May 7-18, 2001 by a mission composed of Mr. Luc Lerath (Mission Chief), Ms. Dawn Rehm (Fiscal Affairs Department, IMF) and Mr. Georges Toussaint (IMF Resident Expert at WAEMU in Ouagadougou).

${ }^{2}$ These include (i) the Constitution (www.primature.gov.bf/tepublic/constitution.htm) (Loi No. 002/97/ADP); (ii) Ordonnance No. 69-047/PRES/MFC of September 18, 1969 (as amended) establishing the organic law on budget laws; (iii) Décret No. 69-197/PRES/MFC of September 19, 1969 (as amended), establishing the financial rules and regulations applicable to the government; and (iv) Décret No. 97-164/PRES/MEF of April 17, 1997 establishing the general regulations applicable to government accounting. Provisions for inclusion of local government finances are treated in paragraph 4
} 
harmonization of government finance. In this context, a new law covering the responsibilities and operations of the Cour des comptes was adopted during 2001, and a new draft organic law for the budget has been approved by the council of ministers and has been passed to the National Assembly for consideration. ${ }^{3}$

\section{The legal basis for fiscal management is under revision. Historically, fiscal} management has been highly centralized, and the central government authorities exercise close supervision over the decentralized entities. In common with all countries following the French administrative tradition, fiscal management is organized around the principles of demarcation between the functions of the authorizing officer (ordonnateur) and accounting officer (comptable), with procedures for the supervision of government expenditures. The Minister of Economics and Finance is the sole officer allowed to authorize expenditure commitments and issue payment orders (ordonnancements). Existing legislation (see paragraph 1) specifies that the Minister of Economics and Finance prepares the draft budget appropriation laws that are subsequently adopted by the National Assembly, and is responsible for budget execution. ${ }^{4}$ Under the draft organic budget law, the ability of the National Assembly to amend the annual budget law (loi de finances) would be limited to proposals that would reduce expenditures or increase revenues ${ }^{5}$ Government accounts are currently audited by the accounts division of the Supreme Court, until the recently created Cour des comptes (Audit Office), establishes sufficient capacity to take on its responsibilities. ${ }^{6}$

\section{Financial relationships between the various layers of Government are evolving:} the underlying principles have been clearly established in legislation.? Government operations have historically been highly concentrated, with the central government generally delivering services directly to local communities. As a result, budgets for districts (communes) are small, and are not consolidated into a picture of general government. This is

${ }^{3}$ Loi Organique No 14-2001/AN (as anended) Portant Composition, Attribution, Organisation, Fonctionnement de La Cour Des Comptes Et Procédurer Applicable Devant Elle, and Project de Loi Portant Loi Organique Relative aux Lois de Finances (respectively).

${ }^{4}$ The structure of government is similar to that of other countries in the region: the President is the head of state, and appoints the Prime Minister, who is the head of goverrment

${ }^{5}$ See Article 50 of the draft organic budget law, Project de Loi Portant Loi Organique Relative atx Lois de Finances.

${ }^{6}$ Under the WAEMU Transparency Code for the Management of Public Finances, each member country is required to establish Audit Court (Cour des comptes) by end-December 2002.

${ }^{7}$ In particular, laws covering the organization of provinces and communes and the decentralization process were adopted in 1998. Loi No. 42/98/AN Portant Organization and Fonctionnement des Collectivités Locales ; Loi No. 41/98/AN Relative à l'Organisation de l'Administration du Territoire au Burkina Faso; Loi No. 40/98/AN Portant Orientation de la Décentralisation au Burkina Faso. 
changing as the government gradually implements a program of deconcentration and decentralization of resources to local governments (provinces, communes) as mandated by legislation adopted in $1998 .^{8}$ The package of legislation includes provisions for a phased reallocation of resources and responsibilities over a 5-year period, ending in August 2003.' While the laws grant districts and provinces financial autonomy, the central government retains authority (autorite de tutelle) regarding the approval of local budgets. ${ }^{10}$ While both provincial and district governments are permitted to borrow, in general this to is subject to approval by central government representatives. Laws adopted in 1998 specify certain resources for provincial and district (communes) governments. As responsibilities devolve to lower levels of government, the allocation among lower levels of government (across districts, provinces) and between levels of government (between provinces and districts) will be refined. Included in the legislation already adopted are provisions for the central government to step in the event that subnational levels of government are faced with a shortfall of resources.

\section{Government intervention in public enterprises is limited, and privatization has}

been transparent. The first two stages of the privatization process have been completed, and some 47 public enterprises, which comprised about 80 percent of the government's initial portfolio, have been liquidated or sold. Significant progress has been made in the third part of the program, which focuses on the public utilities and cotton sector. Information on the status of enterprises being sold or under liquidation is readily available from the WAEMU web site. ${ }^{11}$ Recent progress notwithstanding, some major corporations remain in the government's hands - particularly in the cotton, hotel, energy and communications sectors. The status of the government's equity holdings are publicly available and are monitored by the treasury (see list in Annex I). Privatization receipts are passed to the budget, usually net of operating costs of the privatization agency.

\footnotetext{
${ }^{8}$ To date, the deconcentration has been limited to a system of delegated credits, which decentralize commitments. All actual expenditures continue to be ordered by the budget directorate in Ouagadougou.
}

9 The laws mandate that the decentralization and deconcentration of responsibilities be accompanied by an appropriate reallocation of resources. The time frame over which this is to take place is determined in Loi No. 43/98/AN Portant Programmation de la Mise en Oeuvre de la Decentralization, also adopted in 1998. The law provides for a 3-year period (ending August 2001) in which to evaluate the resources that will need to be transferred to meet legally mandated responsibilities. An overlapping 5-year delay in implementing Laws No. 40/98/AN-42/98/AN is established to allow for the development of local institutional capacity for both districts (communes) and provinces, and implementation of the actual deconcentration of responsibilities.

\footnotetext{
${ }^{10}$ Under Law 42/98/AN, Articles 170-172, and 202 the supervisory authorities comprise the Minister of Local Administration and Decentralization, and the Minister of Economics and Finance. These same articles provide for the adoption of a budget nomenclature by local governments prescribed by the Council of Ministers (on advice from the Minister of Finance).
}

"The site www.izf.net/izf/Opportunities/Default.htm contains a link for ongoing privatization throughout the WAEMU. 


\section{While the government has reduced its holdings in the banking sector, the} allocation of responsibilities between the banking system and the government lacks clarity. Although the government now retains only minority share boldings ( 25 percent) in selected private banks, in some cases the government has retained sufficient authority to name the managing director of some private sector banks. Moreover, the government does continue to engage in its own banking activities, as the Comptes chèques postaux (CCP) and the Postal Savings Bank (CNE) are still public financial institutions: the activities of these institutions are, however, clearly distinguished from budget activities. The treasury also engages in some limited direct banking operations through its management role with regard to two types of deposit accounts: (i) the accounts of specific public entities which, in Frenchspeaking Africa, are required to deposit their cash resources with the treasury; and (ii) a limited number of deposit accounts opened voluntarily by private enterprises.

\section{The government does not use the central bank to carry out quasi-fiscal} operations; provision of credit to the government by the central bank is prohibited. Burkina Faso is one of eight countries that belong to WAEMU, and the Central Bank of West African States (BCEAO) serves all members as a common central bank. The BCEAO is responsible for implementing a common monetary policy that emphasizes the stability of the CFA franc and does not engage in quasi-fiscal activities on behalf of its membership. Under a decision recently taken by the WAEMU, the BCEAO should have ceased to provide advances to member countries from January 2002. However, outstanding advances were not all repaid by end-December $2001 .^{12}$

\section{Official regulation of the private nonbanking sector is transparent, and} information is readily available. Commercial regulations for Burkina Faso now fall largely under the harmonized statutes arising from the Treaty on the Harmonization of Business Law in Africa. ${ }^{13}$ The legal framework also includes the Investment Code, the Mining Code, and the Labor Code, along with provisions for product standards; price setting has been eliminated. ${ }^{14}$ The legal provisions are straight forward, and are generally applied. In the context of the implementation of the WAEMU reforms the Government has designed a

\footnotetext{
${ }^{12}$ The BCEAO transfers dividends from profits (net of reserves and costs) to member countries on an annual basis. The BCEAO maintains a web site www.bceav.int.

${ }^{13}$ The treaty had 16 signatories, and related uniform acts cover general commercial law (1997), commercial companies and economic interest groups (1997); securities markets (1997); claims recovery (1998); bad debt write off (1998), and arbitration (1999). The treaty and legislation can be found at www.jurisint.org/pub/ohada/index_fr.html (or www.jurisint.org/pub/ohada/index en.html).
}

${ }^{14}$ The Investment Code and Mining Code are publicly available from a number of web sites, including the Chamber of Commerce www.primature.gov.bf/infopratique/fsites.htm. Information on minimum wages and overtime pay is available through the WAEMU investment website at www.izf.net/izf/Guide/Burkina. Related provisions include product standards (Décret 94-014, January 1994). 
reform program, which emphasizes a streamlining of existing regulations applying to private entities, including the elimination of preferential arrangements for specific enterprises.

\section{Shortcomings have been identified in the area of government contracts,} including the practice of splitting up contracts in an attempt to bypass regulations. A number of abuses of power have also been identified. The need to remedy these deficiencies has led to a decision by the authorities to revise the procurement code.

\section{The government's accounts are currently being harmonized with WAEMU} standards. ${ }^{15}$ Budgetary and accounting procedures are largely computerized, and an integrated financial management and information system covers current expenditures and domestically financed capital expenditures. The system is not yet fully linked to the treasury, and does not cover externally financed capital expenditures.

\section{Legal provisions governing tax and customs regulations are clearly defined and} readily available. Taxpayers' tax-related obligations are clearly defined in the legislative texts, which are duly cited in the budget laws for each tax and duty. The tax laws are summarized in a code, which may be purchased from the General Directorate of Taxes. A statement of the tax obligations for enterprises is readily available from the WAEMU investment web site, and the Minister of Economy and Finance regularly publishes information on tax reforms, changes, and procedures. A number of initiatives, more closely tailored to local conditions, are implemented with the aim of educating Burkina Faso taxpayers (e.g., publication of a timetable of obligations for taxpayers). The external tariff is common to WAEMU countries and information on rates and exemptions is readily available. ${ }^{16}$ There is no formal code of taxpayer rights.

\section{Civil servants are not subject to a separate code of good conduct. While the} Constitution establishes some general principles and obligations for higher officials, there is no specific code of conduct for government employees. However, in common with all the countries of French-speaking Africa, there are general and special civil service regulations (Statutes de la fonction publique), which establish the rights and obligations of civil servants, and are used as way to mandate ethical rules. There is at present no anticorruption legislation.

\footnotetext{
${ }^{15}$ See Directive 04/97/CM/UEMOA relating to the Lois de Finances (budget law), and Directive 06/97/CM/UEMOA relating to Règlement Général sur la Comptabilité Publique (regulation of public accounts). Also, Directive No. 04/98/CM/UEMOA Portant Nomenclature Budgetaire de l'État (budget nomenclature for WAEMU member states). All are accessible through www.izf.net/izt/Documentation/JoumalOfficiel.
}

${ }^{16}$ See http://www.izf.net/izf/TEC/Default.htm. 


\section{B. Public availability of information}

\section{The public has access to some annual information on past and projected fiscal} activity. No information is released to the public during the fiscal year. The public has access to the annual budget laws (published in the Official Gazette and available on the Ministry of Economics and Finance website), which include projections for the following two years, as well as estimated outturn data for the two previous years. Information on the final accounts has been subject to significant lags. The final budget execution acts containing annual outturn data for 1995-98 are still under consideration for presentation to parliament. Information on actual outturns will be included once these reports (loi de règlement) are presented to and adopted by parliament. It is expected that the latter will be brought up to date by end-2002

15. While indicators of the fiscal policy stance are used in preparing the budget law, not all of this information is directly reflected in the budget documents. The explanatory memorandum to the budget law spells out the government's fiscal objectives. A macroeconomic framework that sets medium-term goals for each component in the government's Summary Table of Fiscal Operations (TOFE) determines these objectives. The framework also provides information on debt sustainability. The Planning Ministry in preparing the Poverty Reduction Strategy Paper (PRSP), which is publicly available, has also performed long-term forecasting exercises, focusing inter alia on government finance categories. ${ }^{17}$

\section{Budget documents provide information for central government budget} transactions, but not detailed information on financing for the budget deficit. The coverage of the budget is limited to the activities of the central government. While central government transfers are captured in the budget, the revenues and expenditures of local governments and agencies are not. Thus, consolidated data on the general government is not readily available. Some aggregates are described in the explanatory memorandum to the budget law. Historical information on the budget law is limited, however, to budget forecasts with respect to revenues for the two preceding fiscal years.

\section{Budget documents do not as yet include information on economic risks or} contingent liabilities. Burkina Faso is considering new legislation consistent with WAEMU principles, including the Transparency Code for Fiscal Management, that would expand the information provided to the National Assembly to include contingent liabilities and own revenues, as well as the balance sheet of the state; provisional financing plans of the treasury (monthly); and a functional and economic presentation of the budget.

17 The PRSP is available in both English and French on the Ministry of Finance web site www.finances.gov.bf/fr/default htm.

${ }^{18}$ See www. izf.net/izf/Documentation/JournalOfficiel/AfriqueOuest/2000/Ann DIR $0200 . h \mathrm{htm}$. The WAEMU Transparency code establishes a number of principles for coverage of the budget and documentation 
18. Burkina Faso has adopted General Data Dissemination Standards (GDDS) as its statistical development framework in January 2001 and draft metadata were prepared for all sectors. There are also ongoing efforts, in conjunction with Fund staff in particular, to enhance data quatity and to improve the frequency of data disclosure.

\section{Open Budget Preparation, Execution, and Reporting}

19. As with other WAEMU countries, the medium-term fiscal policy objectives are established with reference to the conditions of the convergence and stability pact. The fiscal criteria of the pact's first tier include: basic balance (target: at least positive balance); ${ }^{19}$ total public debt (target: less than 70 percent of GDP); and no external or domestic payment arrears. The second tier targets include tax revenue (target: at least 17 percent of GDP). The authorities intend to meet the highest number of targets possible by end-2002, but will need some time to observe criteria pertaining to tax receipts as a percent of GDP, and the external current account (excluding grants) as a percentage of GDP. ${ }^{20}$

The use of extrabudgetary funds is limited for the recurrent budget but it is substantial, however, with regard to the capital budget. There is a considerable gap between total capital or development spending, and amounts captured in the central government budget. One exception concerns development funds for most departments that are financed by extrabudgetary revenues originating, inter alia, from penalties imposed by the General Directorate of Taxes or the General Directorate of Customs. The allocation of these funds is determined by ministerial decrees, and the extent of government activities financed in this manner is limited. However, most departments have a capital development fund financed by extrabudgetary revenue, which comes mainly from penalties levied by the General Directorate of Taxes and the General Directorate of Customs. The allocation of this revenue is organized by ministerial decree. The actual use of these resources is not with budget operations, which skews the budget law results, both revenue and expenditure, downward. More important, while the General Directorate for International Cooperation in the Ministry of Economics and Finance tracks implementation of the foreign financed capital budget, the results are not integrated into the general budget, and are not consolidated with other fiscal operations in budget execution statements.

to be provided to the National Assembly and to the public. The requirement that ail members establish and implement extemal audit agencies (Audit Courts) is also part of these requirements.

${ }^{19}$ The basic fiscal balance is defined as revenue (excluding grants) minus expenditure excluding foreignfinanced investment outlays.

${ }^{20}$ Information on the relevant indicators for Burkina is available through the WAEMU web site www.izf.net/izf/Guide/Burkina Faso/Default.htm. 
20. Current services appropriations [services votés] are clearly distinguished from new budget measures at the time the budget is prepared. This procedure is formalized as part of a two-stage budget preparation process under the draft organic budget law currently before parliament. The authorities plans to include explicit risk assessments to ensure that contingencies are taken into account when preparing the annual budget.

21. Timely information on implementation of the recurrent budget is available internally. Reliable information on the implementation of the capital budget is problematic. Preliminary statements of government flow-of-funds are available monthly, within three weeks of the end of the month under consideration. Similarly, information on the financial accounts of the government is distributed monthly, albeit to a limited group, and more extensive reports are provided on a quarterly basis. While in-year information on budget execution has not been available to the public, the government intends to improve the information flow using the government's web site. ${ }^{21}$ With regard to the capital budget, the lack of accuracy for foreign-financed development expenditure financed seems greater as regards implementation. However, considerable work has been done to improve matters in the context of the PRGB (plan to strengthen expenditure management), approved by the council of ministers on September 12, 2001.

\section{The Minister of Economy and Finance prepares detailed data on budget} execution for the council of ministers, but the report is not published. Moreover, some types of information are thus far available only when specifically requested, including the functional classification of expenditure. Outturn data on actual expenditures funded by donors and lenders are available to some extent, from specific sources. However, these data are imprecise and are not uniformly available in a timely manner. Contingent liabilities and tax expenditures (specifically tax exemptions) are not discussed in any specific statement at this time.

\section{The authorities have largely implemented WAEMU directives on budget} nomenclature, and a programmatic classification for most ministries. The budget is presented, voted on, and executed in accordance with an administrative classification of services and expenditures by type. While economic and functional classifications have been entered into the computer system, these are not as yet produced or published on a regular basis. Programmatic budgeting was initially introduced in 1999 for six ministries (defense, health; basic education, secondary and higher education; finance; and regional government). While all ministries now provide draft program budgets, the quality remains uneven for ministries other than the original six. sectoral programs, which are used for budget planning, are not included in budget documents.

21 The ministry has created a web page (www.finances.gov.Burkina Faso), and plans to gradually update the web and release certain types of government budget and finance data to the public. Additional information on Burkina Faso may also be consulted at the WAEMU's web page (www.uemoa.int). 
24. Information on government procurement and civil service conditions is publicly available. Government procurement procedures are specified in a code (décret No. 96059/PRES/PM/MEF), which is currently under review. These procedures are available through the Ministry of Finance web site, and detailed information is available through the WAEMU site. ${ }^{22}$ Procurement procedures are monitored, and abuses may be appealed. A number of abuses have been identified, and the authorities have decided to revise the code. Civil service recruitment is conducted on the basis of competitive examination. The career streams, pay scales, and working conditions for government employees are set in the civil service regulations. The salary grids are clearly defined and are in the public domain.

\section{Budget operations are recorded on a cash basis for revenues, and they are} recorded on a commitment basis for expenditures. The treasury's accounting system also makes it possible to track disbursements. Accounting adjustments are needed in order to prepare outturn statements so as to take account of operations conducted during the supplemental fiscal period, to reflect data pertaining to capital expenditures directly paid for by donors and lenders, and to identify problems currently encountered in producing balances.

26. The controls over budget operations are well defined, but are largely limited to a test to verification that procedures have been followed; the control procedures are not, in general, subject to independent scrutiny. Controls over commitment and internally financed expenditures have at times covered total transfers, rather than particular expenditures. Externally funded capital expenditures may be checked only by the General Directorate for Cooperation (Direction Générale de la Coopération), which reviews disbursement requests. Payment verification by the Direction Centrale du Contrôle Financier is largely equivalent to an examination of a claim's validity and verification of the availability of funds (i.e. an accounting control).

27. Provisions guaranteeing the independence of tax and customs administration are in the annual budget law. Provisions in the annual budget law explicitly provide for the independence of all directorates and agencies in charge of revenue collection. Further, it is forbidden for a minister or head of agency to interfere with the functioning of the directorate or agency under his supervision in ways that block or impedes legal procedures that apply to public accountants in matters pertaining to revenue collections. ${ }^{23}$

28. The authorities have begun (with assistance from the World Bank) to implement a more complete system of payment controls, as part of a system of managerial and internal control procedures. These would replace existing mechanisms of cash rationing. Under current procedures, when cash flow pressures become excessive, the Minster of

22 Information on public offers can be found at www.izf.net/izf/opportunities/default.htm; procedures are described on www.finances.gov.bf/fr/debut.hts.

${ }^{23}$ See Articles 5 and 6 of the Loi de Finances, Gestion 2001 . 
Economics and Finance has the authority to freeze specific budget appropriations. At the same time, a monthly cash-flow plan prepared by the treasury used by the Cash Flow Committee (chaired by the Minister of Economics and Finance) to determine which expenditures will be authorized for payment. Priority is generally assigned to statutory outlays (wages and external debt service) and priority sectors.

\section{Some internal audit functions are in place, but mostly undertake specific} requests. The main mechanisms of internal control include the General Inspectorate for Finance, which is directly responsible to the Minister of Economy and Finance and usually undertakes specific requests issued by the Minister of Economy and Finance. There is also a general inspectorate for the state, which reports directly to the Prime Minister and the President, and also undertakes investigations in response to specific requests from the Prime Minister or the President.

\section{Independent Assurances of Integrity}

There is generally a close correspondence between the current budget and its implementation: budget execution for foreign financed capital expenditure is not included in execution reports. Deviations for 2000 were exceptional, and reflected a greater than anticipated reduction in resources after the implementation of the WAEMU common external tariff (CET). Budget forecasts for foreign investment are generally overstated, both in terms of disbursements and outlays.

30. External audit functions are being developed. Final accounts for 1995-98 are not yet available. After a lapse of a number of years, the accounts division of the Supreme Court is doing external verification of these accounts. While this is properly the domain of the Audit Court (Cour des comptes), the latter has not yet been effectively installed. While neither agency has sufficient resources, the shortfall for the Audit Court is exceptionally acute. Personnel with the correct qualifications have not been hired and, despite legal requirements to the contrary, most existing personnel are on a temporary secondment from the Ministry of Economics and Finance.

\section{Domestic experts do not review the main budget assumptions and}

macroeconomic models. In general, these reviews are confined to discussions with the Bretton Woods Institutions. A general discussion is included in the budget package presented to the National Assembly and published on the Ministry of Economics and Finance web site.

32. The National Institute of Statistics (INSD) mainly processes government finance statisties, which is a general directorate of the Ministry of Economy and Finance. While there are technical assurances of independence, the INSD has quite limited resources at its disposal. 


\section{IMF STAFF COMMENTARY}

\section{Burkina Faso is undertaking a range of efforts to achieve greater fiscal} transparency. Key elements include improvements to the legal framework, progress in privatization and withdrawal to a considerable extent from financial sector activities. Full implementation of the WAEMU directives, include the transparency code, will build upon the results achieved thus far. In a number of areas, substantial improvements require only that existing information or processes be distributed more widely. In other areas, more concerted efforts will be required (see last two paragraphs on the Audit Court and the decentralization process).

\section{The legal framework applicable to government finance is currently being} modernized and harmonized with WAEMU directives. The government has adopted the drafts for the new legislation; and the draft organic law on budget laws has been filed with the Bureau of the Assembly. Provisions are already included in the draft to ensure that the central government budget is all-inclusive in terms of both receipts and expenditures, something already largely implemented. Materials provided to parliament along with the budget would be expanded to include multi-year projections of debt service obligations, lists of all special accounts and expenditures related thereto; the government balance sheet; monthly projections for budget implementation; and functional and economic classifications for the budget. The law itself does not, however, mandate that parliament receive material on past budgets and their implementation or material from the medium term expenditure framework for future years. ${ }^{24}$ While the authorities plan to include the latter in the materials presented to parliament, the draft organic budget law could be used to ensure that law mandates these materials. A second point concerns the absence of any reference in the organic budget law to the development of consolidated accounts or their presentation to parliament as legislation regarding the devolution of responsibilities to lower governments is implemented.

\section{The separation of responsibilitles between the banking sector and the} government need to be clarified. Even though government holdings of private barks have been reduced to 25 percent, the government has nonetheless succeeded in appointing some Managing Directors. This prerogative, where it still exists, should be relinquished. Moreover, the treasury should consider discontinuing its banking activities relating to private deposit account management.

36. The transparency of the tax systern would be improved with a formal declaration of taxpayer rights, and a strengthening of the judicial system to ensure that challenges can be considered in a timely manner. Transparency is relatively well established with regard to

${ }^{24}$ These are not mandated at present by WAEMU legislation. 
taxpayer obligations, owing in part to coordination under the WAEMU. There is no code of taxpayer rights, however, and the legal system lacks an explicit tax court staffed with magistrates and personnel with sufficient training to handling issues related to taxation.

\section{Public access to information could be strengthened in important ways relatively} easily. Public access to information has been improved in recent years through the development of the Ministry of Economy and Finance web site and the publication of the PRSP. Information available through the web site is limited, however, to the budget law and basic information on the estimated outturn for previous years. Additional information on the macroeconomic framework, government objectives and in-year reports on budget execution is available and could be included.

38. The transparency of budget documents would be improved if the functional and economic budgetary classifications were to be published in a systematic fashion. Some information on budget implementation for 1999 and 200 has recently been made available on the web site. A better-organized presentation of information will be important for the credibility of the PRSP and HIPC process. Data dissemination efforts (SDDS and GDDS) are still pending.

\section{Information on the budget outturn should be expanded to include information} on the externally financed capital budget. The absence of such information limits the transparency of outturn information and assessments regarding government priorities. A substantial improvement in this regard could be addressed quite readily: information on externally financed capital outlays is collected by the General Inspectorate for International Cooperation, and could be included in statements of budget execution. It may be difficult in the short term to ensure that information on externally financed capital expenditures is comprehensive and available within the same time frame as recurrent spending. Nevertheless, the government could take steps to improve on the coverage and timeliness of information provided by ministries and donors.

40. The controls over budget execution are deficient and in need of improvement. Existing controls are limited to simple tests (performed by the Financial Control Unit of the Ministry of Economy and Finance) to verify that the budget procedures have been correctly applied in the execution of expenditures. The system allows operations to be recorded in an exhaustive manner. While accounting system is broadly comprehensive, accounting balances have not been produced for several years, owing to longstanding anomalies. Rectification of these problems is critical for the production of accurate accounting information basic transparency

\section{The WAEMU timetable for producing final accounts should be implemented,} and steps taken to ensure that treasury and management accounts are prepared and forwarded to the external audit office. Under WAEMU regulations, the accounts for fiscal year (N-1) must be submitted to the National Assembly prior to the adoption of the budget law for fiscal year $(\mathrm{N}+1)$. Major efforts are urgently needed to bring the accounts up to date 
and ensure that these deadlines are met in the future. Normally, the budgetary accounts should be accompanied by the management accounts of the government's main accounting officers. To date, however, the latter have not been prepared or provided. This raises substantive legal issues for accounts currently under review: if the management account for 1994 were rejected by the accounts division or the Audit Court, the audited budget execution act for 1994-already adopted by the National Assembly-would have to be invalidated.

42. External audit functions could be improved. Existing laws require that the budgetary accounts for the year be submitted to the Audit Court, then to the National Assembly. However, the delays encountered in submitting the accounts to the audit authority-currently the accounts division of the Supreme Court-have been so long as to render the auditor's examination meaningless. The most recent fiscal year submitted to the legislature for approval was 1994, and the accounts for FY 1995-98 are only now being examined. The authorities are committed to bringing the external audit process into compliance with the WAEMU directive on budget laws, which requires that budget review laws be submitted to the legislative branch within a year of the closing of the fiscal year in question. Although serious efforts have recently been made, the catch up period is expected to last through 2003 .

43. The Audit Court is not yet fully operational. Although the accounts division of the Supreme Court was converted to the Audit Court under the latest amendment to the Constitution, the Audit Court has only recently been officially installed and thus allowed to legally operate. However, its human and physical resources-which are very limited-are insufficient to allow it to discharge its responsibilities fully. The Audit Court currently consists of just two magistrates and a few advisors. The advisors are appointed for a renewable term of office of five years, and return automatically to the civil service once their term of office is over. This undermines any sense that the Audit Court is truly independent of the government agencies that they are supposed to be auditing.

\section{Measures are needed to ensure that the legally mandated decentralization and} deconcentration does not undermine fiseal transparency. Local revenues at present are small, limiting the impact of their omissions from budget reporting for transparency. A range of laws aimed at deconcentration and decentralization have been adopted that lay the basis for devolution of fiscal resources and responsibilities expected to begin shortly. If the processes of budget preparation, monitoring, and reporting are to remain open, central government procedures will need to be extended to subnational levels of government, and a framework for consolidated general government reporting will need to be put into place. 
Burkina Faso: Government Equity Participations in the Economy.

\begin{tabular}{|c|c|c|c|c|c|}
\hline Enterprises & Sector & $\begin{array}{l}\text { Perecntage Cap. } \\
\text { Held by } \\
\text { Govemernent }\end{array}$ & Capital & $\begin{array}{l}\text { Cap. Held by } \\
\text { Governement }\end{array}$ & $\begin{array}{l}\text { Percentage } \\
\text { of Total }\end{array}$ \\
\hline \multicolumn{6}{|c|}{ Residual government portfolie } \\
\hline ONEA & Water & 100.00 & $3,080,000,000$ & $3,080,000,000$ & 2.77 \\
\hline SONAPOST & Postal services/savings bank & 100.00 & $2,590,000,000$ & $2,590,000,000$ & 2,33 \\
\hline CBMP & Gold & 100.00 & $550,000,000$ & $\$ 30,000,000$ & 0.49 \\
\hline $\cos 2 i$ & Stabilization of rice prices & 100.00 & $\ldots$ & $\ldots$ & $\ldots$ \\
\hline LONAB & Lottery & 100.00 & $1,000,000,000$ & $1,000,000,000$ & 0.90 \\
\hline SONAGESS & Management of buffer food stocks & 100.00 & $200,000,000$ & $200,000,000$ & 0.18 \\
\hline MEDIFA & Pharmaccutical & 100.00 & $400,000,000$ & $400,000,000$ & 0.36 \\
\hline ONBAH & Damsiririgation & 100.00 & $800,000,000$ & $800,000,000$ & 0.72 \\
\hline ONPF & Wells and drilling & 100.00 & $1,156,270,000$ & $1,156,270,000$ & 1.04 \\
\hline SIBAM & Arms & 72.00 & $40,000,000$ & $28,800,000$ & 0.09 \\
\hline BUMIGEB & Mining & 100.00 & $900,000,000$ & $900,000,000$ & 0.81 \\
\hline CCVA & Automobile-technical sontrols & 100.00 & $300,000,000$ & $300,000,000$ & 0.27 \\
\hline CENATRIN & Computer and data processing & 100.00 & $183,819,000$ & $183,819,000$ & 0.17 \\
\hline HOTEL FNDEPENDANCE & Hotęs & 100.00 & $828,000,000$ & $828,000,000$ & 0.74 \\
\hline HOTEL SILMANDE & Hotels & 91.00 & $1,600,600,000$ & $1,456,000,000$ & 1.31 \\
\hline LNBTP & Consiruction' public works & 100.00 & $318,000,000$ & $318,000,000$ & 0.29 \\
\hline SONATUR & Construction/ publie works & 100.00 & 10.000 .000 & $10,000,000$ & 0.01 \\
\hline SOPAFER & Rail transport & 100.00 & $1,000,000,000$ & $1,000,000,000$ & 0.90 \\
\hline BIB & Banking & 23.00 & $4,800,000,000$ & $1,104,000,000$ & 0.95 \\
\hline $\mathrm{BCB}$ & Banking & 30.00 & $3,300,000,000$ & $1,650,000,000$ & 1.48 \\
\hline SGGB & Banking & 15.00 & $1,600,000,000$ & $240,000,000$ & 0.22 \\
\hline BICLA-B & Banking & 25.00 & $5,000,000,000$ & $1,250,000,000$ & 1.12 \\
\hline CNCA & Banking & 25.00 & $3,500,000,000$ & $875,000,000$ & 0.79 \\
\hline SOTRAO & Rosd transport & 25.00 & $1,100,000,000$ & $275,000,000$ & 0.25 \\
\hline SITARAIL & Kailways & 15.00 & $5,000,000,000$ & 750.000 .000 & 0.67 \\
\hline SOFITEX & Cotton ginning & 35.00 & $4.000 .000,000$ & $1,400,000,000$ & 1.26 \\
\hline SOF & Briek factery & 100.00 & $1,000,000,000$ & $1,000,000,000$ & 0.90 \\
\hline Total & & & & $23,344,889,000$ & 20.97 \\
\hline
\end{tabular}

Source: IMF, EBS/01/84, June 2001, 